\title{
MODEL KEBIJAKAN HUKUM DESENTRALISASI PENGELOLAAN LINGKUNGAN HIDUP BERBASIS PENDEKATAN EKOSISTEM
}

\author{
Muhammad Akib dan Muhtadi \\ Dosen Bagian HAN dan HTN Fakultas Hukum Universitas Lampung
}

\begin{abstract}
Conceptually, policies of environmental decentralization aims to environmental conditions will be better. But the reality since the enactment of Act No. 22 of 1999 (now replaced by Act No. 32 of 2004) environmental damage tends to increase. This study aims to find a model appropriate legal policy in environmental management. The method used depart from the doctrinal legal research, which is reviewing all legal product both at national and local levels Lampung related to environmental management. As a complement to use socio-legal method. The results of this research show that the legal policy of decentralization is not reflecting the ecosystem approach, among other because of the strong interest of the sector, the domination of economic interests, and the weakness of good governance. The ideal legal policy model is to combines aspects of democratization and the sustainability of ecosystems. This model is implemented in the division of authority, institutional capacity of the environment and interregional cooperation
\end{abstract}

Kata kunci : legal policy, decentralization, environment

\section{PENDAHULUAN}

Kebijakan hukum otonomi daerah yang ditandai dengan lahirnya Undang-Undang Nomor 22 Tahun 1999 yang kemudian diganti dengan Undang-Undang Nomor 32 Tahun 204 tentang Pemerintahan Daerah memberikan implikasi terhadap penyelenggaraan pemerintahan. Berbagai urusan yang semula menjadi wewenang pusat, kini menjadi wewenang daerah atau setidaknya diselenggarakan bersama antara pusat dan daerah. Kebijakan ini secara hakiki bertujuan agar daerah dapat menyelenggarakan pemerintahan sendiri atas dasar prakarsa, kreativitas dan peran aktif masyarakat dalam rangka mengembangkan dan memajukan daerahnya dan meningkatkan kesejahteraan masyarakat secara menyeluruh.

Implikasinya, desentralisasi dan otonomi daerah dalam segala urusan pemerintahan, termasuk dalam bidang lingkungan harus diletakkan dalam upaya mewujudkan kesejahteraan rakyat melalui pengelolaan lingkungan yang baik. Pencemaran-kerusakan lingkungan akibat penyelenggaraan pemerintahan daerah yang tidak berbasis keberlanjutan ekologis tidak akan mampu mewujudkan kesejahteraan masyarakat secara berkelanjutan. Karena itu, melalui otonomi daerah secara ideal kondisi lingkungan di daerah akan semakin baik (Keraf, 2002; Soemarwoto, 2004; http:// www.bapedal.go.id, diakses 19 Maret 2002). Kondisi 
ideal tersebut akan tercapai jika didukung oleh kebijakan hukum yang berbasis pada keberlanjutan ekosistem.

Secara konstitusional basis keberlanjutan ekosistem dalam pengelolaan lingkungan dan pembangunan telah ditetapkan dalam Pasal 33 ayat (3) dan (4) UndangUndang Dasar Tahun 1945 (UUD Tahun 1945). Idealnya, semua kebijakan hukum di bawahnya merefleksikan prinsip-prinsip yang dianut UUD Tahun 1945. Namun sejak berlakunya Undang-Undang Nomor 22 Tahun 1999, banyak kebijakan hukum desentralisasi yang tidak memperhatikan pendekatan ekosistem. Akibatnya, proses desentralisasi yang seharusnya berdampak positif bagi lingkungan justeru menunjukkan sebaliknya. Banyak penelitian menunjukkan bahwa berbagai kasus lingkungan, termasuk di lokasi penelitian tetap saja terjadi, bahkan dan cenderung meningkat di era otonomi daerah (Nurjaya, 2008; Akib, 2008).

Berdasarkan latar belakang di atas maka masalah penelitian ini dapat dirumuskan sebagai berikut:

(1) Mengapa kebijakan hukum desentralisasi dan otonomi daerah pengelolaan lingkungan hidup yang tercermin dalam produk hukum otonomi daerah bidang lingkungan hidup tidak berbasis pendekatan ekosistem dan tipologi daerah?

(2) Bagaimanakah model kebijakan hukum desentralisasi dan otonomi daerah pengelolaan lingkungan hidup yang berbasis pendekatan ekosistem dan selaras dengan tipologi daerah?

Tujuan khusus dari penelitian ini adalah untuk merumuskan model kebijakan hukum desentralisasi dan otonomi daerah pengelolaan lingkungan yang berbasis pendekatan ekosistem, yang meliputi aspek wewenang dan kelembagaan serta kerjasama antardaerah dalam pengelolaan lingkungan.

\section{METODE PENELITIAN}

Penelitian ini adalah penelitian hukum doktrinal (yuridisnormatif) yang mengkaji ketentuan hukum desentralisasi lingkungan dengan menggunakan statute approach, analytical approach, dan conceptual approach. Adapun Pendekatan socio-legal juga digunakan sebagai pelengkap untuk menganalisis fenomena hukum dan implikasi sosial-ekonomi penerapan otonomi daerah di bidang lingkungan. Bahan hukum yang digunakan adalah bahan hukum primer dan bahan hukum sekunder, yang dikumpulkan melalui studi kepustakaan, indept interview, dan Focus Group Discusion (FGD), serta dianalisis secara deskriptif-analitik.

\section{HASIL PENELITIAN DAN PEMBAHASAN}

\subsection{Kebijakan Hukum Desentrali- sasi dan Otonomi Daerah Pengelolaan Lingkungan Hidup}

Secara historis kebijakan hukum otonomi daerah telah muncul sejak kolonial Belanda melalui penerapan Decentralitatie Wet 1903 dan Inlandsche Gemeente Ordonnantie (IGO) 1906 (Wignyosoebroto, 2005). Kemudian hanya berselang tiga bulan setelah Indonesia merdeka, kebijakan desentralisasi ditetapkan dengan Undang-Undang Nomor 1 Tahun 
1945 tentang Kedudukan Komite Nasional Daerah. Kebijakan ini terus berganti seiring dengan dinamika politik yang berlaku, yaitu mulai dari Undang-Undang Nomor 22 Tahun 1948, Undang-Undang Nomor 1 Tahun 1957, Undang-Undang Nomor 18 Tahun 1965, Undang-Undang Nomor 5 Tahun 1974, UndangUndang Nomor 22 Tahun 1999, dan terakhir Undang-Undang Nomor 32 Tahun 2004 tentang Pemerintahan daerah, yang diubah terakhir dengan Undang-Undang Nomor 12 Tahun 2008.

Dinamika tersebut sekaligus menggambarkan kuatnya tarik-ulur antara pusat dan daerah dalam penyelenggaraan pemerintahan. Hal ini seharusnya tidak dimaknai sebagai ajang untuk membagi-bagi kekuasaan, tetapi lebih ditujukan untuk kemadirian dan kesejahteraan daerah melalui pengelolaan lingkungan yang baik. Jesse C Ribbot (2004:8) dalam hal ini menyatakan, bahwa desentralisasi merupakan suatu cara untuk meningkatkan efisiensi dan keadilan dalam pengelolaan sumber daya alam. Melalui efisiensi dan keadilan inilah, otonomi daerah akan memberikan dampak positif bagi lingkungan hidup.

Berlakunya Undang-Undang Nomor 22 Tahun 1999 tentang Pemerintahan Daerah, yang kini diganti dengan Undang-Undang Nomor 32 Tahun 2004 sebagiamana diubah terakhir dengan UndangUndang Nomor 12 Tahun 2008 merupakan titik balik penyelenggaraan pemerintahan yang sebelumnya bersifat sentralistik menjadi desentralistik. Sejak saat itu terjadi arus balik kekuasaan dari pusat kepada daerah (Sarundajang, 1999). Hampir semua urusan pemerintahan yang sebelumnya menjadi urusan pusat diberikan kepada daerah atau setidaknya dikelola bersama antara pusat dan daerah, termasuk dalam bidang pengelolaan lingkungan hidup. Hal ini telah ditegaskan lebih lanjut dalam Peraturan Pemerintah Nomor 38 Tahun 2007 tentang Pembagian Urusan Pemerintahan antara Pemerintah, Pemerintah Daerah Provinsi dan Pemerintah Daerah Kabupaten/Kota.

Kelemahan dari pembagian urusan tersebut bahwa urusan pengelolaan lingkungan lebih dimaknai sebagai urusan "pengendalian dampak lingkungan". Padahal, pengelolaan lingkungan memiliki lingkup yang luas, yaitu mulai dari perencanaan, pelaksanaan, pengawasan, dan penegakan hukum. Pembagian urusan pengelolaan lingkungan dalam PP tersebut juga tetap mempertahankan sifatnya yang sektoral, karena dalam berbagai urusan sektoral (seperti kehutanan, pertambangan, pengairan, dan lainlain) terdapat pula pembagian urusan yang terkait dengan pengelolaan lingkungan.

Di Propinsi Lampung dan beberapa kabupaten/kota yang menjadi lokasi penelitian ini kewenangan daerah telah ditetapkan Peraturan Daerah (Perda), yaitu:
(1) Perda Propinsi Lampung Nomor 3 Tahun 2009 tentang Urusan Pemerintahan Daerah Propinsi Lampung.
(2) Perda Kabupaten Lampung Tengah Nomor 11 Tahun 2007 tentang Kewenangan Pemerintah Daerah Kabupaten Lampung Tengah
(3) Perda Kota Bandar Lampung Nomor 1 Tahun 2008 tentang 


\begin{abstract}
Urusan Pemerintahan Daerah Kota Bandar Lampung

Hasil penelitian terhadap substansi Perda tersebut menunjukkan hal yang sama dengan pusat, karena pada dasarnya merupakan "copy paste" dari PP No. 38 tahun 2007. Dengan kata lain kebijakan hukum daerah yang terkait dengan lingkungan juga bersifat sektoral dan lebih difokuskan pada aspek pengendalian lingkungan. Mengingat Perda ini menjadi dasar dalam penetapan kelembagaan daerah, maka urusan lingkungan selain diselenggarakan oleh kelembagaan lingkungan, juga diselenggarakan oleh berbagai lembaga daerah lainnya yang terkait dengan pengelolaan lingkungan.
\end{abstract}

Temua lainnya bahwa di daerah Lampung tidak banyak Perda yang secara khusus ditujukan untuk pengelolaan lingkungan. Dalam wilayah Propinsi Lampung hanya ada dua Perda dan satu Peraturan Bupati yang secara khusus mengatur pengelolaan lingkungan yaitu:

(1) Peraturan Daerah Propinsi Lampung Nomor 3 Tahun 2006 tentang Pengelolaan Sumber Daya Alam dan Lingkungan Hidup.

(2) Peraturan Daerah Lampung Barat Nomor 18 Tahun 2004 tentang Pengelolaan Sumber Daya Alam dan Lingkungan Berbasis Masyarakat.

(3) Peraturan Bupati Pesawaran Nomor 3 Tahun 2008 tentang Pengendalian Pencemaran Limbah Cair di Kabupaten Pesawaran.

Perda lainnya yang terkait dengan lingkungan umumnya Perda tentang pajak dan retribusi lingkungan. Secara filosofis Perda tersebut seharusnya ditujukan untuk pengelolaan lingkungan, tetapi dalam kenyataannya tidak lebih sebagai upaya untuk meningkatkan Pendapatan Asli Daerah (PAD). Dengan demikian dapat disimpulkan bahwa pendekatan sektoral dan parsial serta dominasi kepentingan ekonomi itulah yang menyebabkan kebijakan hukum otonomi daerah tidak berbasis ekosistem.

\subsection{Dampak Kebijakan Hukum Desentralisasi dan Otonomi Daerah Terhadap Lingkungan Hidup}

Dampak dari kebijakan hukum yang tidak berbasis ekosistem merupakan salah satu alasan banyaknya Perda yang dibatalkan karena dianggap bertentangan dengan peraturan yang lebih tinggi dan/atau kepentingan umum, termasuk kepentingan perlindungan lingkungan. Menurut data Departemen Dalam Negeri, sejak otonomi daerah berlaku efektif mulai tahun tahun 2001 sampai dengan Desember 2008 Menteri Dalam Negeri telah menolak 267 Rancangan Perda dan membatalkan 2.431 Perda dari 11.638 Perda yang diajukan kepada Menteri Dalam Negeri (Departemen Dalam Negeri, 2009).

Di Provinsi Lampung, sejak otonomi daerah ada 30 (tiga puluh) Perda kabupaten/kota tentang pajak dan retribusi daerah yang dibatalkan, sebagian berkaitan dengan lingkungan, sebagaimana dalam tabel 1.

Hasil penelitian menemukan bahwa Perda tersebut dibatalkan karena bertentangan dengan peraturan perundang-undangan yang lebih tinggi dan atau kepentingan umum, termasuk dalam bidang 
perlindungan lingkungan. Dengan kata lain visi dikeluarkannya Perda tersebut sebenarnya bukan untuk perlindungan lingkungan, melainkan untuk meningkatkan PAD. Bahkan di daerah Lampung pernah dikeluarkan Perda yang secara substansi sama dengan Perda yang pernah dibatalkan dan akhirnya dibatalkan kembali. Sebagai contoh, telah dibatalkannya Perda Provinsi Lampung Nomor 9 Tahun 2000 tentang Retribusi Izin Penyimpanan/Penimbunan Semen dan Batubara serta Mineral Lainnya, namun kemudian dibuat Perda yang sama dengan dikeluarkannya Perda Provinsi Lampung Nomor 7 Tahun 2001 tentang Retribusi Izin Penyimpanan/ Penimbunan Semen dan Batubara serta Mineral Lainnya.

Dampak berikutnya adalah menurunnya kualitas lingkungan di daerah, termasuk di Provinsi Lampung. Angka kerusakan hutan semakin bertambah, meningkatnya lahan kritis, dan pencemaran air semakin sering terjadi. Sementara penegakan hukum oleh kelembagaan lingkungan (hukum administratif) tidak efektif.

Menurut data SLHD Provinsi Lampung (2008), kerusakan hutan baik hutan lindung maupun produksi saat ini telah mencapai sekitar $60 \%$ dari luas lahan yang ada, yakni 1,237 juta hektar. Lahan kritis dapat dijumpai di seluruh wilayah Provinsi Lampung dengan total lahan kritis kurang lebih 647.747,05 hektar.Berdasarkan angka ini tercatat $5,25 \%$ tergolong sangat kritis, $10,04 \%$ kritis, $35,29 \%$ agak kritis, $29,96 \%$ kritis, dan hanya $19,45 \%$ tergolong tidak kritis. Bahkan lahan kritis ini tidak hanya terdapat di dalam dan di luar kawasan hutan, tetapi juga di Daerah Aliran Sungai (DAS). Sebagai akibat maka hampir seluruh DAS di Lampung mencatat angka fluktuasi debit air yang tinggi yaitu dari $61,08 \%$ hingga $429,77 \%$, kecuali Way Semangka $6,7 \%$ dan Way Rarem 23,24\%.

Tabel 1.

Perda Kab/Kota Provinsi Lampung yang Berkaitan dengan Bidang Lingkungan Hidup Dibatalkan Mendagri (2001-2008)

\begin{tabular}{|c|c|c|}
\hline Daerah & No / Thn & Peraturan Daerah \\
\hline \multirow[t]{5}{*}{ Provinsi Lampung } & No.7/2000 & $\begin{array}{l}\text { Retribusi Izin Pemungutan Terhadap Pengambilan } \\
\text { Hasil Hutan Bukan Kayu di Kawasan Hutan }\end{array}$ \\
\hline & No.8/2000 & $\begin{array}{l}\text { Retribusi Pengangkutan Bahan Galian Batubara, } \\
\text { Bahan Baku Semen dan Barang-Barang Potensial } \\
\text { Lainnya }\end{array}$ \\
\hline & No.9/2000 & $\begin{array}{l}\text { Retribusi Izin Penyimpanan/Penimbunan Semen dan } \\
\text { Batubara serta Mineral Lainnya }\end{array}$ \\
\hline & No.10/2000 & $\begin{array}{l}\text { Retribusi Pelayanan Karantina Hewan, Ikan, dan } \\
\text { Tumbuhan }\end{array}$ \\
\hline & No.7/2001 & $\begin{array}{l}\text { Retribusi Izin Penyimpanan/Penimbunan Semen dan } \\
\text { Batubara serta Mineral Lainnya }\end{array}$ \\
\hline Kab. Lampung Selatan & No.21/2000 & Retribusi Izin Gangguan \\
\hline Kab. Lampung Utara & No.7/1999 & $\begin{array}{l}\text { Pajak Pemanfaatan Air Bawah Tanah dan Air } \\
\text { Permukaan }\end{array}$ \\
\hline
\end{tabular}




\begin{tabular}{|c|c|c|}
\hline & No.4/2002 & $\begin{array}{l}\text { Pajak Pengambilan dan Pengelolaan Bahan Galian } \\
\text { Gol. C }\end{array}$ \\
\hline & No.5/2003 & Retribusi Sarang Burung Walet \\
\hline Kab. Lampung Barat & No.8/2001 & Pengendalian Penebangan dan Peremajaan \\
\hline \multirow[t]{2}{*}{ Kab. Tulang Bawang } & No.11/2003 & $\begin{array}{l}\text { Retribusi Pemanfaatan SDA Daerah untuk Usaha } \\
\text { Bidang Perkebunan }\end{array}$ \\
\hline & No.6/2004 & $\begin{array}{l}\text { Retribusi Pungutan Dana Pengawasan Pencemaran } \\
\text { Limbah Industri Tapioka }\end{array}$ \\
\hline Kab. Tanggamus & No.7/2000 & Retribusi Izin Usaha Alat Mesin Pertanian \\
\hline \multirow[t]{4}{*}{ Kab. Lampung Timur } & No. $10 / 2001$ & $\begin{array}{l}\text { Retribusi Atas Izin Peruntukan dan Penggunaan } \\
\text { Tanah }\end{array}$ \\
\hline & No.15/2002 & $\begin{array}{l}\text { Retribusi Izin Usaha Tanaman, Benih/Bibit serta } \\
\text { Pengelolaan Hasil Perkebunan dan Kehutanan }\end{array}$ \\
\hline & No.17/2002 & $\begin{array}{l}\text { Retribusi Izin Pemanfaatan, Pemupukan, dan } \\
\text { Penggunaan Alat Pengolahan Hasil Hutan Kayu dan } \\
\text { Non Kayu Kabupaten Lampung Timur }\end{array}$ \\
\hline & No.11/2004 & Retribusi Izin Pembuangan Limbah Cair \\
\hline
\end{tabular}

Sumber: Departemen Dalam Negeri (Diolah), 2009

Kondisi tersebut harus segera diatasi karena menyebabkan kekurangan air pada musim kemarau, tetapi kelebihan air pada musim hujan. Penyebab utamanya antara lain karena rusaknya fungsi hidrologis kawasan hutan lindung dan kondisi tanah setempat yang relative porous. Untuk mengatasi berlanjutnya kerusakan lingkungan tersebut maka tidak ada pilihan lain kecuali melalui kebijakan hukum yang benar-benar berpihak pada keberlanjutan ekosistem dan dilaksanakan secara konsisten.

\subsection{Model Kebijakan Hukum Desentralisasi dan Otonomi Daerah Pengelolaan Lingkungan Hidup Berbasis Pendekatan Ekosistem}

\footnotetext{
Model kebijakan hukum desentralisasi pengelolaan lingkungan yang berbasis ekosistem setidaknya meliputi aspek pembagian wewenang, kelembagaan lingkungan daerah, dan kerjasama antardaerah. Mengenai pembagian wewenang,
}

melalui Undang-Undang Nomor 32 Tahun 2009 tentang Perlindungan dan Pengelolaan Lingkungan Hidup daerah telah diberi wewenang yang luas untuk melakukan perlindungan dan pengelolaan lingkungan hidup. Hal ini sekaligus menunjukkan keinginan yang kuat dari pembentuk undang-undang untuk mendukung pelaksanaan desentralisasi dan otonomi daerah yang telah digulirkan sejak tahun 1999 melalui UndangUndang Nomor 22 Tahun 1999 dan kemudian diganti dengan UndangUndang Nomor 32 Tahun 2004 tentang Pemerintahan Daerah. Sayangnya kebijakan baru ini tidak selaras dengan Undang-Undang Nomor 32 Tahun 2004 dan PP No. 38 Tahun 2007 yang terlihat masih mengkotak-kotakkan urusan pengelolaan lingkungan.

Hasil kajian secara mendalam terhadap PP No. 38 Tahun 2007 menunjukkan bahwa yang dimasukkan dalam klasifikasi urusan lingkungan lebih difokuskan pada aspek "pengendalian lingkungan hidup". Karena itu dalam PP ini 
urusan pengelolaan lingkungan masih tersebar dalam berbagai urusan lainnya, seperti urusan kehutanan, pertambangan, dan lain sebagainya. Dengan demikian pendekatan yang digunakan dalam pembagian urusan pemerintahan bukan pendekatan ekologi secara utuh, tetapi masih menggunakan pendekatan sektoral. Implikasi dari ketentuan yang demikian ini maka tidak heran jika pengelolaan lingkungan hidup di daerah hingga saat ini masih bersifat parsial dan sektoral. Urusan pengelolaan lingkungan yang menjadi tugas dan tanggung jawab kelembagaan lingkungan daerah akan terbatas pada aspek "pengendalian lingkungan" semata, bahkan kewenangan pengendalian tersebut dalam kebijakan hukum pusat maupun daerah tidak dilengkapi dengan kewenangan penegakan hukum.

Secara ideal model pembagian wewenang pengelolaan lingkungan hidup dalam kerangka otonomi daerah harus didasarkan pada pendekatan ekosistem dan pengaturannya di daerah harus disesuaikan dengan tipologi ekosistem daerah. Pendekatan yang demikian tentu memiliki implikasi bahwa urusan lingkungan yang menjadi tugas dan wewenang daerah tidak dipotong-potong hanya pada aspek pengendalian semata, tetapi mulai dari perencanaan, pelaksanaan, pengawasan sampai pada penegakan hukumnya. Pemberian wewenang kepada daerah juga tidak dibuat seragam untuk semua daerah, tetapi benar-benar didasarkan pada karakteristik ekosistem yang ada di daerah. Konsekuensi yuridisnya bahwa pengaturan beberapa urusan lingkungan yang hingga kini masih tersebar pada sektor-sektor harus disatukan menjadi urusan bidang pengelolaan lingkungan hidup. Kegiatan-kegiatan sektor, seperti kehuatan, pertambangan, dan lainlain sepanjang terkait dengan pengelolaan lingkungan harus disatupadukan dengan urusan lingkungan.

Untuk itu diperlukan kelembagaan lingkungan yang kuat dan mandiri, yang sebenarnya belum dimiliki hingga saat ini. Kelembagaan lingkungan daerah yang sekarang dibentuk berdasarkan Undang-Undang Nomor 32 Tahun 2004 jo. PP No. 41 Tahun 2007 tentang Organisasi Perangkat Daerah tidak memiliki wewenang eksklusif karena hanya difokuskan pada teknis-administratif pengendalian dampak. Nomenklatur-nya pun hingga saat ini berbeda-beda (ada yang bernama badan, kantor, atau digabung dengan dinas tertentu) tanpa wewenang pengawasan dan penegakan hukum yang jelas. Sementara wewenang koordinasi sifatnya lebih kepada teknisadministratif, sehingga pelaksanaannya masih sangat tergantung pada departemen atau dinas daerah yang secara sektoral diberi tugas dan wewenang tertentu.

Penguatan kelembagaan ini dapat dilakukan dengan penyatuan beberapa wewenang pengelolaan lingkungan yang kini tersebar pada beberapa dinas daerah. Instrumen hukum yang dapat digunakan adalah melalui kewenangan perizinan lingkungan yang secara formal telah diakui dalam Undang-Undang Nomor 32 Tahun 2009. Melalui instrumen izin, kelembagaan lingkungan dapat melakukan pengawas-an dan sekaligus penegakan hukum. Sebagai konsekuensinya maka model 
kelembagaan yang tepat adalah berbentuk Dinas Daerah, yang kalau dikaitkan dengan Undang-Undang Nomor $\quad 32$ Tahun 2009 nomenklaturnya adalah Dinas Perlindungan dan Pengelolaan Lingkungan Hidup Daerah. Kelemahan wewenang koordinasi dapat diatasi dengan mewajibkan izin lingkungan sebagai syarat diterbitkan-nya izin usaha atau kegiatan. Dengan demikian, instansi lain yang memiliki kewenangan perizinan usaha akan selalu berkoordinasi dengan kelembagaan lingkungan yang memiliki kewenangan untuk menerbitkan izin lingkungan sebelum diterbitkannya izin usaha.

Pengelolaan lingkungan tidak dapat dibatasi secara ketat berdasarkan batas administrasi, sehingga diperlukan kerjasama antardaerah. Kerjasama antar-daerah dibutuhkan untuk mencegah terjadinya konflik antar-daerah yang bersumber dari pemanfaatan sumber daya alam. Salah satu prinsip yang dapat digunakan adalah bioregionalism atau yang menurut Undang-Undang Nomor 32 Tahun 2009 dikenal dengan prinsip ekoregion. Melalui prinsip ini dapat diintegrasikan berbagai ekosistem yang kini cenderung dikelola secara terpisah oleh masing-masing daerah. Melalui pendekatan ini pula kewenangan daerah tertentu dalam suatu batas administrasi akan disesuaikan dengan perencanaan kegiatan dalam satu wilayah yang telah ditetapkan dalam suatu ekoregion.

Undang-Undang Nomor 32

Tahun 2009 belum mengatur secara jelas tentang kerja sama antardaerah. Pasal 63 hanya menegaskan wewenang pemerintah dan pemerintah daerah untuk mengembangkan dan melaksana-kan kerja sama antardaerah. Sementara Undang-Undang Nomor 32 Tahun 2004 tentang Pemerintahan Daerah juga belum mengatur secara jelas tentang kerja sama antardaerah. Pasal 195 dan 196 hanya memberikan arahan untuk dilaksanakannya kerjasama antardaerah. Demikian pula dengan PP No. 50 Tahun 2007 tentang Tata Cara Pelaksanaan Kerjasama Daerah, sifatnya lebih kepada teknis kerjasama dan bukan kepada substansi kerjasama.

Pengelolaan lingkungan memiliki karakteristik tersendiri dibandingkan dengan urusan-urusan lainnya, terutama karateristik sumber daya alam, ekosistem, kondisi geografis, budaya masyarakat setempat, dan kearifan lokal. Karena itu memerlukan pengaturan tersendiri dan model yang dikembangkan tergantung pada karakteristik ekosistem daerah. Model-model ini dapat berupa pengelolaan DAS, model cost sharing, pengelolaan taman nasional terpadu, pengelolaan wilayah pesisir, pengelolaan sampah, dan lain-lain (Lihat Kementerian Lingkungan Hidup, 2006).

Provinsi Jawa Barat, Banten, dan Jawa Tengah misalnya, telah menerapkan model kerjasama melalui pendekatan DAS dan cost sharing (Forum DAS Lampung, 2009). Model ini dapat diterapkan di Provinsi Lampung, karena hampir semua kabupaten/kota-nya berada dalam dua DAS besar, yaitu DAS Sekampung dan DAS Seputih. DAS Way Sekampung secara administratif melibatkan Tanggamus, Bandar Lampung, Lampung Selatan, Lampung Timur, Metro, dan Lampung Barat, Pesawaran dan Pringsewu. Sedangkan DAS Way 
Seputih melibatkan Kabupaten Tanggamus, Lampung Utara, Lampung Tengah, Lampung Timur, Metro, Lampung Barat, Tulang Bawang dan Lampung Selatan, Pesawaran, Pringsewu, dan Tulang Bawang Barat. Model cost costsharing dapat diterapkan antara Kota Bandar Lampung dan Kabupaten Pesawaran sebagai catchments area dan sumber air PDAM Bandar Lampung dan beberapa beberapa kabupaten/kota lainnya yang berada dalam kawasan DAS.

\section{PENUTUP}

\subsection{Simpulan}

1. Kebijakan hukum desentralisasi pengelolaan lingkungan belum mencerminkan pendekatan ekosistem, antara lain karena kuatnya kepentingan sektor, dominasi kepentingan ekonomi, dan tidak lemahnya good governance.

2. Dampak kebijakan hukum yang demikian adalah kerusakan lingkungan cenderung meningkat. Kerusakan hutan semakin bertambah, luasan lahan kritis bertambah dan dapat dijumpai di seluruh wilayah Provinsi Lampung, dan semua sungai di Provinsi Lampung kini dalam status tercemar.

3. Model kebijakan hukum desentralisasi yang berbasis pendekatan ekosistem tercermin dalam pembagian wewenang yang tidak hanya difokuskan pada aspek pengendalian semata, melainkan secara integral meliputi semua aspek mulai dari perencanaan, pelaksanaan, pengawasan hingga penegakan hukum. Kelembagaan lingkungan daerah memiliki tugas dan wewenang pengelolaan lingkungan secara komprehensif mulai dari perencanaan, pelaksanaan, sampai pada pengawasan dan penegakan hukum. Model kerjasama antardaerah dalam pengelolaan lingkungan yang berbasis ekosistem di Lampung antara lain dapat berupa pengelolaan DAS terpadu dan model Cost sharing.

\subsection{SARAN}

1. Perlu dilakukan reorientasi kebijakan hukum desentralisasi yang memadukan aspek demokratisasi dan keberlanjutan ekosistem, sehingga tujuan otonomi daerah akan tercapai tanpa merusak daya dukung lingkungan.

2. Untuk mencegah meluasnya dampak negatif dari kebijakan otonomi daerah yang telah dikeluarkan, selain diperlukan evaluasi kebijakan juga diperlukan komitmen yang kuat dari pejabat pemerintah, dunia usaha, dan masyarakat untuk melakukan upaya-upaya pencegahan dan penangulangan pencemaran ataupun sampa pada kerusakan lingkungan.

3. Perlu pengaturan secara khusus kerjasama antardaerah di bidang pengelolaan lingkungan hidup, karena PP No. 50 Tahun 2007 sifatnya sangat umum dan lebih banyak mengatur tata cara pelaksanaan kerjasama daerah. Diperlukan produk hukum masing-masing daerah untuk menindaklanjuti Keputusan Bersama Kepala Daerah yang merupakan landasan awal kerjasama daerah. 


\section{DAFTAR PUSTAKA}

Akib, Muhammad. 2008. Hukum Lingkungan, Kebijakan dan Pengaturan Global dan Nasional, Bandar Lampung: Lemlit Unila Press.

Cheema, G. Shabbir \& Dennis A. Rondinelli, (ed). 1983. Decentralization and Development, $\quad$ Policy Implementation in Developing Countries, California: Sage Publications, Inc. Baverly Hills.

Hadi, Sudharto P. 2002. Dimensi Hukum Pembangunan Berkelanjutan, Semarang: BP Undip.

Hadjon, Philipus M., et.al. 1993. Pengantar Hukum Administrasi Indonesia, Yogyakarta: Gadjah Mada University Press.

Hadjon, Philipus M.. 1994. "Fungsi Normatif Hukum Administrasi Dalam Mewujudkan Pemerintahan Yang Bersih", Pidato Peresmian Penerimaan Jabatan Guru Besar Ilmu Hukum, Surabaya: Fakultas Hukum Unair.

Heryandi, Akib, Tisnanta. 2005. Pemberdayaan Masyarakat Dalam Pengelolaan Wilayah Pesisir Pantai Timur Lampung Selatan, Penelitian Hibah Bersaing DIKTI 2003 dan 2004 (dipublikasi dalam Seri Monograf, Pusat Penelitian Lingkungan Unila, Bandar Lampung.

Indroharto. 1991. Usaha Memahami Undang-Undang tentang
Peradilan Tata Usaha Negara, Jakarta: Pustaka Sinar Harapan.

Keraf, A. Sonny. 2002. Etika Lingkungan, Jakarta: Penerbit Buku Kompas.

Manan, Bagir. 1994. Hubungan Antara Pusat dan Daerah Menurut UUD 1945, Jakarta: Pustaka Sinar Harapan.

Manan, Bagir. 2001. Menyongsong Fajar Otonomi Daerah, Yogyakarta: PSH FH UII.

Marzuki, H.M. Laica. 2007. "Hakikat Desentralisasi Dalam Sistem Ketatanegaraan RI", Jurnal Konstitusi, Volume 4 No. 1.

Nurjaya, I Nyoman. Moratorium Logging Dalam Perspektif Antropologi Hukum, http://www.manifestmaya.blo gspot.com/2008/01/moratoriu m-logging-dalam-perspek-tif$\underline{\mathrm{html}}$, Diakses 3 Januari 2008.

Ribot, Jesse C. 2004. Waiting For Democracy, The Politics of Choice in Natural Resource Decentralization, Washington DC: World Resorces Institute, 2004.

Santosa, Mas Achmad. 2001. Good Governance dan Hukum Lingkungan, Jakarta: ICEL.

Sarundajang 1999. Arus Balik Kekuasaan Pusat ke Daerah, Jakarta: Pustaka Sinar Harapan.

Soemarwoto, Otto., Ekologi, Lingkungan Hidup dan Pembangunan, Cet. Kelima, Djambatan, 1991.

Sumaryadi, I Nyoman. 2005. Efektivitas Implementasi Kebijakan Otonomi Daerah, Citra Utama, Jakarta.

Wijoyo, Suparto. 2005. Hukum Lingkungan: Kelembagaan 
Fiat Justitia Jurnal Ilmu Hukum Volume 5 No. 2 Mei-Agustus 2012, ISSN 1978-5186

Pengelolaan Lingkungan di

Press, Surabaya, 2005.

Daerah, Airlangga University 